C., Lim, R.K.S., PotTer, G.D. AND Rodgers, D.W.: Narcotic and non-narcotic analgesics which block visceral pain evoked by intra-arterial injection of bradykinin and other algesic agents. Archs int. Pharmacodyn. Ther. 149, 571-588(1964); 3) Kant:ko, T., SATo, M. AND TAKAGI, H.: Central actions of bradykinin in rabbits and thcir modification by analgesics. Folia pharmacol. japon. 65, 176-181 (1969) (Abs. in English): 4) Graef, F.G., Pilí, I.R. and Rocha E Silva, M.: Bchavioural and somatic effects of bradykinin injected into the cerebral ventricles of unanaesthetized rabbits. Brit. J. Pharmacol. 37, 723-732 (1969): 5) Dor, T., Akalkf, A., Ohashi, M., Satoh, M. AND TAKAGr, H.: Bradykinin-induced flexor reflex of rabbit hindlimb for comparing analgesics. Japan. J. Pharmacol, 26, 634-637(1976); 6) MurA, S. AND OGuRA, Y.: Effects of atropine and vagotomy on vocalization of the rabbil. Iapam. I. Phimacol. 28, 331-334 (1978); 7) TalRA, N., NaKayama, K. Avi Hashimoto, K.: Vocalization response of puppies to intra-arterial administration of bradykinin and other algesie agents and mode of actions of blocking agents. Tohoku J. exp. Med. 96,365-377(1968); 8) CARROL 1, M.N. A.ND LIM, R.K.S.: Observations on the neuropharmacology of morphine and morphine-like analgesia. Archs int. Pharmacodyn. Ther. 125, 383-403 (1960); 9) Horfmeister, F.: Effects of psychotropic drugs on pain. Pain. Edited by Soulairac, A., Cahn, J. and Charpentiele, J., p. 309-319, Acadenic Press, New York and London (1968); 10) Lim, R.K.S., Gujmay, F., Rodgrers, D.W., Goro, K., Braun, C., Dicktrson, G.D. and ENGiLl, R.J.: Site of action of narcotic and non-narcotic analgesics determined by blocking brallykinin-cvoked visceral pain. Archs int. Pharmacodln. Thér. 152, 25-58 (1964); 11) JAIt., J.H. AND MARTIN, W.R.: Nareotic analgesies and antagonists. The Pharmacological Basis of Therapeutics, Fifth cdition, Edited by GoOnmar, L.S. And GILman, A., p. 245-283, MacMillan Publishing Company, New York (1975); 12) Satoh, M., DoI, T., Kawasaki, K., Akake, A. AND TAKAGI, H.: Effects of indomethacin and the other anti-inflammatory agents on activation of dorsal horn ecll in the spinal cord induced by intra-artcrial injection of bradykinin. Japan. $J$. Pharmacol. 26, 309-314 (1976)

\title{
COMPARISON BETWEEN FLUORIMETRIC AND RADIOCHEMICAL ASSAYS OF IONTOPHORETICALLY RELEASED NORADRENALINE FROM A SEVEN-BARRELED MICROPIPETTE
}

\author{
Masashi SASA, Seishi IGARASHI, Hiroshi FUJIWARA \\ and Chiyoko INAGAKI \\ Department of Pharmacology, Faculty of Medicine, Kyoto University, \\ Sakyo-ku, Kyoto 606, Japan
}

Accepled April 12, 1978

Microiontophoretic methods coable the study of actions of putative chemical transmitters and central acting drugs on neuronal activity in the central nervous system. Before attempting such neuropharmacological experiments, however, the definite amount of the chemical substance released from a micropipettc has to bo accurately determined. In the present work, we determined the amount of noradrenaline (NA) released from a sevenbarreled micropipette, using a fluorimetric method, and compared the findings with those seen in radiochemical assays.

Aqueous solution containing DL-NA-1-1 ${ }^{\prime}{ }^{3} \mathrm{H}$ with specific activity of $30 \mathrm{Ci} / \mathrm{m}$ mole 
(Commissariat a l'Energie Atomique) was freeze-dried and then dissolved in $250 \mu 1$ of 0.5 M DL-NA hydrochloride solution as described by Hoffer et al. (1). The specific radioactivity of 1 pmol of this $\mathrm{NA}$ solution was approx. 80 disintegrations per min. A sevenbarreled micropipette was filled with $3 \mathrm{M} \mathrm{NaCl}$, and one of the outer barrels was replaced by a solution of $0.5 \mathrm{M}$ unlabelled NA $(\mathrm{pH} 4.5)$ or tritiated NA, using the conventional technique. The electrode tip was manually broken in a manner done for physiological experiments, and then placed vertically into $0.5 \mathrm{ml}$ of Ringer's solution.

NA in the micropipette was released by a current up to $200 \mathrm{nA}$ delivered from a Microiontophoresis Programmer (Model 160, W-P Instruments). The amount of unlabelled NA in the Ringer's solution was microassayed by the modified trihydroxyindole method described by Von Euler and Floding (2), and Anton and Sayre (3). Modification was as follows; the reaction was suspended by adding $0.2 \mathrm{ml}$ of solution containing $2 \mathrm{mg} / \mathrm{ml}$ of ascorbic acid in $5 \mathrm{~N} \mathrm{NaOH} 2 \mathrm{~min}$ after adding $0.02 \mathrm{ml}$ of $0.25 \%$ potassium ferricyanate to $0.5 \mathrm{ml}$ of the simple. This method cnabled the determination of as little as $1.4 \mathrm{ng} / \mathrm{ml}$ of
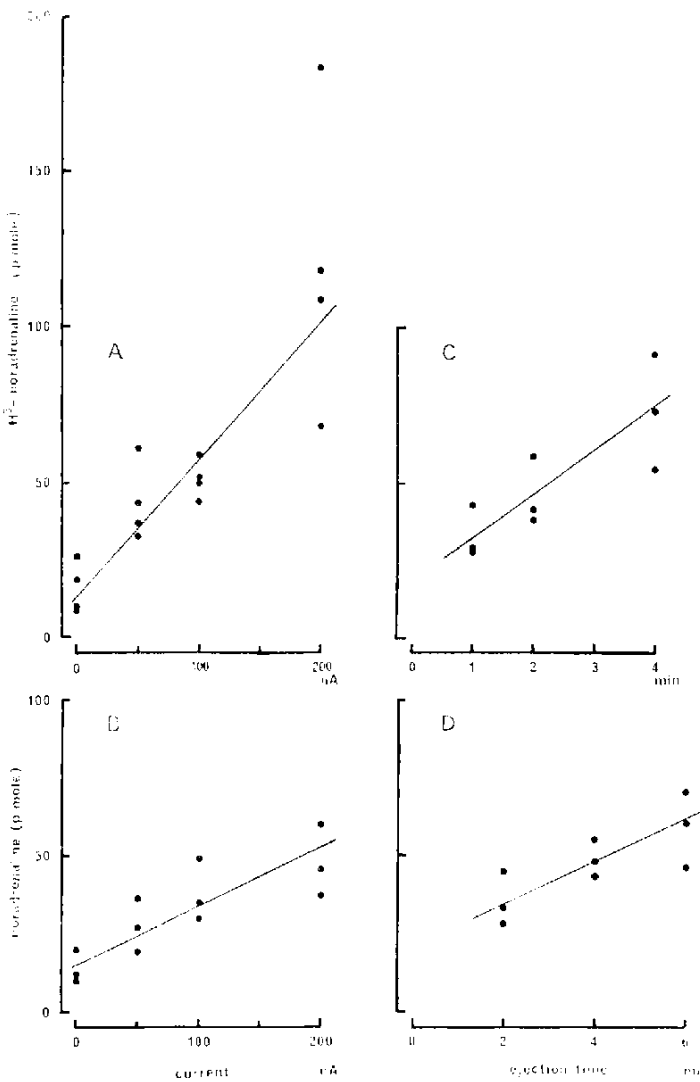

Fig. 1. Relationship between the amount of noradrenaline (NA) released and the ejection current or ejection time. $A$ and $B$ : The amount of $N A$ released against the ejection current for 4 min. $C$ and $D$ : The amount of $N A$ released against the ejection time (min) passed at $100 \mathrm{nA}$. A and C: Radiochemical assay, and $\mathrm{B}$ and $\mathrm{D}$ : Fluorimetric assay. 
NA in standard solution. Tritiated NA released was transferred into a scintillation vial and a total of $10 \mathrm{ml}$ of scintillator was added to each sample. The scintillator contained $0.4 \% 2,5$-diphenyloxazole and $0.01 \% 1 \%$,4-di-2-(5-phenyloxazoly) )-benzene in toluene with $33 \%$ Triton $x-100$. The radioactivity was counted using a liquid scintillation spectrometer (Packard Tris-Carb). The transport number was calculated from the formula: $n=M Z F / I T$, described by Curtis (4). Where, $\mathbf{M}=$ Moles of drug ejected, $Z$--Equivalence/mol, $F=$ Faraday's constant, $\mathrm{I}=$-Ejection current (ampere), and $\mathrm{T}=$ Ejection time (sec).

Fig. $1 \mathrm{~A}$ and $\mathrm{B}$ demonstrates the relationship between the amount of NA released and the current ejected for 4 min. The mean rates of spontaneous release of NA from the micropipette were $3.6 \pm 1.0$ (S.E.) and $3.6 \pm 0.8$ pmole/min with the radiochemical and fluorimetric assays, respectively. A linear relationship between the amount of NA and the ejection current was obtaincd in both measurements, and the correlation coefficients ( $\mathrm{P}<$ 0.01 ) were $0.81 \mathrm{I}$ and 0.827 in the radiochemical and fluorimetric measurements, respectively. A similar linearity was observed between the amount of $\mathrm{NA}$ and ejection time at $100 \mathrm{nA}$ (Fig. IC and D). The correlation coefficients $(\mathrm{P}<0.05)$ were 0.709 and 0.667 on the radiochemical and fluorimetric measurements, respectively. The mean transport number of each pipette was calculated at the ejection current of 50,100 and $200 \mathrm{nA}$ for $2 \mathrm{~min}$. It was $0.23-0.04$ (S.E.) in the radiochemical assays, and $0.15 \pm 0.02$ in the fluorimetric assay (Table 1).

If hydrodynamic outflow of the solution and other factors are disregarded, the rate of spontaneous NA release is theoretically proportional to the concentration of NA in the pipette and square of the tip radius, according to Fick's first law of diffusion. However, it has been demonstrated that the rate of spontaneous release of NA was mainly proportional to the NA concentration rather than the tip radius (5). Therefore, the relatively high rate of NA release in the present experiment is considered to be due to the high concentration of NA in the pipette. The rate and anount of NA obtained herein was comparable to those reported by Hoffer et al. (1), who used the same concentration (0.5 M). The value of NA release which was dependent upon the ejection current by the fluorimetric assay, was also comparable to that reported by Krejvic et al. (6). In the present study, the transport

TAble I. Transport numbers in the radiochemical and fluorimetric measurements

\begin{tabular}{ccc} 
Electrode No. & $\begin{array}{c}\text { Radiochemical } \\
\text { assay }\end{array}$ & $\begin{array}{c}\text { Fluorimetric } \\
\text { assay }\end{array}$ \\
1 & $0.115^{*}$ & 0.116 \\
2 & 0.199 & 0.151 \\
3 & 0.255 & 0.193 \\
4 & 0.346 & 0.153 \\
Mcan & 0.229 & -0.022 \\
S.E. & 0.049 & -0.09 \\
\hline
\end{tabular}

*: Transport number of each pipette was calculated at the current of 50,100 and $200 \mathrm{nA}$ ejected for $2 \mathrm{~min}$, and then the mean of each pipette was obtained. 
number measured by radiochemical assay was larger than that measured by the fluorimetric assay, and such may occur i[ some of radioactivity released is not associated with NA per se (7). Transport numbers reported by other investigators $(1,6,8-10)$ are variable in the range of 0.05 to 0.37 and such is attributed to differences in experimental conditions. The transport number obtaincd herein in both measurements is within the range of these same values. Thus, a linear relationship between the amount of NA release and the ejection time or ejection current was obtained in both radiochemical and fluorimetric measurements. The latter method is simpler and more convenient than the former, because the same microelectrode, from which NA rclease was checked in the latter assay, can also be used for electrophysiological experiments.

\title{
REFERENCES
}

1) Hoffer, B.J., NEFF, N.H. AND Sterins, G.R.: Microiontophoset ic release of norepinephrine from micropipettes. Newopharmacol. 10, 17, 190 (1971); 2) VON LULER, U.S. AND FloDINo, I.: A fluorimetric micromeihod for differential csimation of adrenaline and moradrenaline. Acta physiol. scand. 33, Suppl. 113, 45 56 (:955); 3) Avion, A.H. ANL SAYri, D.1.: A study of the factors afiecting un aluminum oxide trihydroxyind ole procedure for the analysis of calcolumines. J. Pharmacol. exp. Ther. 138, $360375(1962) ; 4)$ C.RTI, D.R.: Microiontophoresis. Plhysical techniques in biological research, Fdited by Nastuk, W.L., Vol. 5, p. 144-171, Acadenic Press, New York and London (1964); 5) BraDSHAw, C.M. AXD SZABADI, E.: The measurement of dose in microelectrophoresis experimcnts. Netwophamacol. 13,407-415 (1974); 6) KRNJEvic, K., LAVHRIY, R. AND SHARMAN, D.F.: Iontophoretic release of adrenaline, noradrenaline and 5-hydroxytryptamine from micropipettes. Brif. J. Phamacol. 20, 49l-496 (1963); 7) Oil LrmaN, J.L. AND MLRrilis, R.J.: The purification of tritiated noradrenaline. Experiehtia 24, $1182-1183$ (1968); 8) Bradshaw, C.M., Robrrts, M.H.T. and Slabadi, E.: Kinetics of the relcase of noradrenaline from micropipettes: Interaction between cjecting and retaining currents. Brit. $J$. Pharmacol. 49, 667-677 (1973); 9) BSADLEY, P.B. AND C.NDY, J.M.: Jontophoretic release of acetylcholine, noradrenaline, 5-hydroxydopamine and D-lysergic acid diethylamide from micropipettes. Brit. J. Phamacol. 40, 194-201 (1970); 10) LAkf, N., Jokdan, L.M., Phillis, J.W. AND Yarbrough, G.G.: The transport number of noradrenaline as a function of pH. $J$. Pham. Pharmacol. 25, 678 (1973)

\section{EFFECTS OF DIFENAMIZOLE ON CONTENT OF CATECHOLAMINES AND METABOLITES IN MOUSE BRAIN}

\author{
Toshitaka NABESHIMA, Kazumasa YAMAGUCHI \\ and Tsutonu KAMEYAMA

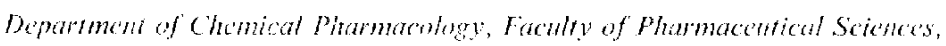 \\ Maijo University, Nagrey 408 , Japan
}

Accepted April 13,1978

In earlier studics in mice, a favorable correlation was found between the analgesic activity and cerebral concentration of 1,3-diphenyl-5-(2-dimethylaminopropionamide)pyrazole[difenamizole, DFZ] (1). In a subsequent study, Nabeshima and Kameyama 